\title{
Bondeskoler og øvrighedsskoler
}

\author{
Af G. Japsen og Troels Fink.
}

Troels Finks vægtige anmeldelse af min bog om det dansksprogede skolevæsen i Nordslesvig indtil 1814 i Sønderjyske Årbøger 1969, I, udmærker sig, fremfor mange andre anmeldelser, ved at tage en række af bogens grundsynspunkter op til drøftelse, ja, indeholder endog en "modtese«. Anmeldelsen får derved for en del karakter af et inspirerende diskussionsindlæg og giver bogens forfatter adkomst til også at yde sit bidrag til debatten.

Uenigheden m. h. t. de konklusioner, der kan drages af det fremlagte materiale, ville næppe have fremkaldt et indlæg fra min side. Der er imidlertid, så vidt jeg kan se, på et centralt punkt i anmelderens betragtninger, tale om en fejlagtig presentation af bogens materiale. En korrektion på dette punkt forekommer mig nødvendig, så meget mere som fejlen med de konsekvenser, den indebxrer, allerede er vandret over $i$ andre anmeldelser.

Spørgsmålet er, hvorvidt overkonsistoriets reskript af 3. 2. 1744, der pålagde kirkevisitatorerne at tage sig af skolebyggeriet, var et tomt påbud eller ej. Herom har jeg bl. a. skrevet (se anmeldelsen, s. 84): "De praktiske resultater blev minimale (og de få skoler, der opførtes $i$ henhold til reskriptet, var sikkert også blevet opført uden dette) ... «. Heroverfor står anmelderens opfattelse (se s. 85): "Det er ikke rigtigt at tale om et tomt påbud. Hvis man slår efter $i$ afhandlingen s. 197 , vil det ses, at der omkring 1740 var ca. 150 skolehuse og omkring $1760 \mathrm{ca}$. 215. Det er næsten en forøgelse på 40 pct. i perioden umiddelbart efter reskriptet af 3. 2. 1744 , selvom vi ser bort fra, hvad der er bygget $i$ årene 1740-44. Der er altså et ganske stærkt byggeri i gang i denne periode, det behøver ikke alt at være foranlediget af reskriptet, men $i$ adskillige tilfxlde kan det dog godtgøres, at det var som følge af reskriptet «. Af sådanne tilfælde nævner anmelderen 4 skoler i Sydslesvig og 3 i Nordslesvig (de 2 i Løjt $\operatorname{sogn}$ ), men mener åbenbart, at en grundigere undersøgelse ville vise, 
at 1744-reskriptet har ført til opførelse af adskilligt flere skolehuse.

Den antagelse, at opførelsen af ca. 65 nordslesvigske skolehuse i tiden 1740-60 overvejende eller blot $\mathrm{i}$ betydelig grad skyldes det nævnte reskript, holder imidlertid ikke stik. En gennemgang af afhandlingens materiale vedrørende disse skolehuse viser nemlig, at et flertal af dem (vistnok 39) på forhånd går fra, fordi de lå i kongerigske sogne, og at en forbindelse mellem skolebyggeriet og reskriptet for de resterende 26 skolehuses vedkommende kun lader sig pâvise i de 3 nævnte tilfælde (Kegnæs er dog noget tvivlsom). Reskriptet spillede altså faktisk en meget ringe rolle for skolebyggeriet $i$ Nordslesvig, og det er sandsynligt, at en nøjere gennemgang af kilderne med henblik på skolebyggeriet i Sydslesvig i årene 1740-60 ville føre til ganske samme resultat.

En dybere virkning af 1744-reskriptet ville også være en overraskelse på baggrund af den viden, man iøvrigt har om resultatet af myndighedernes skoleforordninger. Staten forsøgte i det 17. og 18. århundrede flere gange at bringe de slesvigske landsbyskoler under sin kontrol. I 1650 var der blevet udstedt en skoleforordning for Haderslev provsti, i 1704 fulgte en skoleforordning for Âbenrå amt, i 1744 kom det lige omtalte reskript til fremme af skolebyggeriet i hele Slesvig, og i 1761 fik hertugdømmets kirkevisitatorer vidtgående fuldmagter med hensyn til skolevæsenets indretning. $\varnothing v$ righedens gentagne bestræbelser var imidlertid ikke i stand til at rokke ved den helt dominerende plads, som bondeskolerne indtog $\mathrm{i}$ Slesvig, og situationen var $\mathrm{i}$ det væsentlige uændret lige til udgangen af det 18. århundrede. Kun skolereformen i Haderslev provsti i 1770 erne danner en undtagelse, men den er til gengæld enestående i Slesvig og vistnok $\mathrm{i}$ hele det danske monarki.

Den afgørende forklaring på, at bestrabelserne for at tilvejebringe et statskontrolleret landsbyskolevæsen gang på gang slog fejl, skal næppe søges i den svækkelse af statsmagten, der fulgte i Karl Gustavkrigenes spor. Denne antagelse modsiges bl. a. af, at også de stort anlagte reformforsøg omkring 1740 (især den kongerigske skoleforordning af 1739), altså 80 år efter disse krige, lob ud i sandet. Statens afmagt $\mathrm{i}$ skolesager var lige så stor $\mathrm{i}$ andre lande, og det er tankevækkende, at selv Frankrig og England, Europas højest udviklede stater, først fik et folkeskolevæsen i det 19. århundrede. Det er derfor rimeligt at arbejde ud fra den hypotese, at forudsætnin- 
gerne for tilvejebringelsen af et statskontrolleret skolevæsen i Sønderjylland ikke var til stede før i slutningen af det 18. århundrede.

Alting tyder på, at landsbyskolen i Slesvig udviklede sig i takt med den borgerlige økonomis og den borgerlige idéverdens fremadskridende beherskelse af bondesamfundet. Skolerne opstod på bøndernes initiativ og $\mathrm{i}$ overensstemmelse med deres behov $\mathrm{i}$ landsbyfxllesskabets for staten lukkede verden. Som formidlere af borgerskabets tanker og vurderinger var de en vigtig faktor $i$ landsbyfællesskabets opløsning (at de i deres form svarede til fællesskabet er efter denne betragtning af underordnet betydning). Disse bondeskolers dage var talte med udskiftningens gennemførelse. Da det gamle kollektiv, der havde båret bondeskolerne, forsvandt, måtte statsmagten træde i grandelagets sted, og først da, fra slutningen af det 18. århundrede, var denne store skolereform mulig.

Det bør i denne forbindelse påpeges, at den afgørende forudsætning for degneskolernes opståen var, at degnenes ledige, forudbetalte arbejdskraft her kunne nyttiggøres af bønderne samtidig med, at religionsundervisningen blev kontrolleret af kirken; m. h.t. undervisningens omfang og kvalitet adskilte degneskolerne sig ikke fra de egentlige bondeskoler, og bøndernes indflydelse på disse skolers forhold var langt større end præstens.

I løbet af de 150 år fra 1600 til 1750 blev Nordslesvig dakket af skolehuse, som afløste tidligere tiders omgangsskoler og lejede skolestuer; der havde udviklet sig en stand af professionelle skolelærere, befolkningen var blevet læsekyndig, de fleste drenge lærte at skrive, og det blev forlangt af en lærer, at han kunne undervise i regning og tysk. Undervisningsniveauet i disse bondeskoler lă, efter samstemmende udtalelser, højt over niveauet i de kongerigske skoler.

På baggrund af disse kendsgerninger må jeg afvise anmelderens modtese om, at alene øvrighedsskolerne var udviklingsdygtige. De to skoleformer var tilpasset hver sit historisk betingede miljø og udviklede sig inden for dettes grænse. En vurdering af dem må derfor tage disse relationer som udgangspunkt. Man kan ikke, som det er gjort $\mathrm{i}$ anmeldelsen (s. $75 \mathrm{ff}$.), måle bondeskolerne med de senere øvrighedsskolers alen og sidestille bondeskolernes virkelighed (under den urigtige betegnelse »idealer«) med velmenende menneskers ønsker m. h. t. øvrighedsskoler.

Uenigheden mellem anmelderen og mig bunder, så vidt jeg kan 
se, $i$ en forskellig vurdering af statsmagtens muligheder og hensigter. De modsatte standpunkter m. h.t. mulighederne er trukket op i det foregående, men heller ikke om bedømmelsen af statens hensigter er der enighed mellem os. Det er således meget diskutabelt, om øvrigheden havde en mere human indstilling til landsbyens fattige end bønderne; at der gennem hele det 19. århundrede var en kløft mellem fattige og velhavende børns skolegang, er jo en kendsgerning.

Jeg har med disse bemærkninger til det punkt $i$ anmeldelsen, der for mig er det afgørende, ikke taget stilling til de mange andre spørgsmål, anmelderen kommer ind på, hverken dem, hvor jeg har en afvigende mening, eller dem, som jeg har lagt mig på sinde. Under alle omstændigheder håber jeg, at jeg med mit indlæg har ydet et lille bidrag til klarlæggelsen af skolens lige så vigtige som forsømte historie.

G. Japsen.

\section{REPLIK}

Ved bedømmelsen af en doktorafhandling er det kun muligt for bedømmeren at foretage stikprøver i materialet, og tilfældigvis valgte jeg at undersøge akterne i overkonsistoriets arkiv, og som jeg synes, med stort udbytte.

Det spørgsmål, som er rejst i dr. Japsens indlæg, er ikke begrænset til, om overkonsistoriets reskript af 3 . februar 1744 var et tomt forbud eller ikke, men dette spørgsmål danner det naturlige udgangspunkt.

$\mathrm{Nu}$ er det $\mathrm{i}$ sig selv en meget kategorisk udtalelse at tale om "et tomt påbud «; der skal ikke mange undtagelser til, før man kan sige, at påbuddet ikke er tomt. Men når man står over for disse undtagelser, vil det især være af interesse at undersøge, hvad der bevirkede undtagelserne, og så får man gerne nye problemstillinger. Det er ikke nødvendigt at løse disse nyopdukkede problemer, men det er mere frugtbart at præsentere de nye problemer end at fremsætte en kategorisk påstand.

Det mest nærliggende er dog det principielle moment, der ligger deri, at man må undersøge virkningen af reskriptet i hele Slesvig, når det gælder et materielt forhold som skolebyggeri; et begrænset antal eksempler i Nordslesvig er for en dom ikke tilstrækkeligt; i de materielle forhold bevirkede sprogforskellen ingen naturlig deling, 
man må derfor enten undersøge forholdene i Sydslesvig eller i al fald gøre opmærksom på forholdet. Når dr. Japsen mener, at en nøjere gennemgang af kilderne med henblik på skolebyggeriet i Sydslesvig vil vise, at reskriptet også her spillede en meget ringe rolle, så må det naturligvis komme an på en prove. En forhåndsforventning er uden videnskabelig beviskraft. Det kan højst være en subjektiv antagelse.

Jeg har ikke været opmærksom på, at 39 af de 65 nye skoler, der er bygget mellem 1740 og 1760 , lå $\mathrm{i}$ det kongerigske område, men når forholdet er 3 skoler bygget i Nordslesvig efter reskriptet og 23 uden direkte påvist forbindelse, er dermed relationen sådan set gunstigere for min opfattelse. Man kan yderligere regne med, at en del af de 39 skoler fra tiden 1740-60 i de kongerigske dele er opført på baggrund af påbuddet $i$ den kongerigske skoleforordning af 1739. F. eks. skriver dr. Japsen (s. 140): "Takket være skoleforordningen af 1739 ydede øvrigheden nu støtte til byggeprojekterne og muliggjorde derved deres realisering«. Det er møntet på 4 skolehuse i Als Sønderherred. Om forholdene på Ærø siger dr. Japsen (s. 157): "Der var altså tale om et betydeligt skolebyggeri i tiden efter 1739 ... Man må regne med, at dette skolebyggeri ikke ville være kommet i stand, hvis ikke skoleforordningen af 1739 var blevet udstedt, og hvis ikke bønderne i denne periode havde været i så stærk fremgang i såvel materiel som åndelig henseende«. I enklaverne var skoleforordningen af 1739 mindre betydningsfuld for skolebyggeriet (s. 189). Her blev tilbagetoget med plakaten af 1740 mere påfaldende end på Als; men som helhed kan man vel tillægge den kongerigske forordning af 1739 en lignende betydning som det slesvigske reskript af 1744 og deraf udlede, at de overordnede myndigheders bestræbelser ikke var helt uden frugt.

Det interessanteste ved det materiale, som fremkom som følge af de foranstaltninger, der blev søgt iværksat $i$ henhold til reskriptet af 3. februar 1744, er imidlertid de dokumenter, der viser, hvori vanskelighederne for et statskontrolleret skolevæsen lå, bl. a. vanskeligheden ved at fordele byrderne ved oprettelse og opretholdelse af et skolevæesen, altså de kommunale skatteproblemer i kim.

Øvrighedens andel i skolevæsenets udvikling var ikke begrænset til forsøg på at føre reskripter ud i livet. I talrige tilfælde tilskyndede især præsterne, men undertiden også andre øvrighedspersoner, 
bønderne til en forbedring af skolevæsenet, men jeg er stort set enig med $\mathrm{dr}$. Japsen $\mathrm{i}$, at forudsætningerne for at tilvejebringe et statskontrolleret skolevæsen ikke var til stede før $i$ slutningen af det 18. århundrede, men måske med den forskel, at - efter min opfattelse - dette statskontrollerede skolevæsen har dybe rødder ned i det 17. og 18. århundrede. Jeg er betænkelig ved den formulering, dr. Japsen bruger, når han skriver, »at alting tyder på, at landsbyskolen i Slesvig udviklede sig i takt med den borgerlige økonomi og den borgerlige idéverdens fremadskridende beherskelse af bondesamfundet. Skolerne opstod på bøndernes initiativ og i overensstemmelse med deres behov i landsbyfallesskabets for staten lukkede verden. Som formidlerne af borgerskabets tanker var de en vigtig faktor i landsbyfællesskabets opløsning «.

For det første er ordene »borgerlig" og »borgerskab" her ilde anbragt. Der findes ingen definition på »borgerlig økonomi « og "borgerlig idéverden «. For det andet er der spørgsmålet om »landsbyfællesskabets for staten lukkede verden «. Bondeskolerne hørte ikke kun hjemme, hvor der var landsbyfællesskab; de udviklede sig også i de områder, hvor fællesskabet ikke fandtes, f. eks. i marskområderne. Man må holde sig for øje, at landsbyfællesskabets opløsning var en proces, der strakte sig over 200 år; denne proces var i hele perioden under statsmyndighedernes kontrol, og den kan nøje sættes i forbindelse med de skiftende konjunkturer, men også og måske især med sociale forhold. Udskiftningen var $\mathrm{i}$ dens første faser omkring år 1600 en rationel driftsomlægning, og en forudsætning herfor var bl. a., at bønderne ikke blev tvunget til hovarbejde; den kom igang, uden at skolerne havde formidlet noget af borgerskabets tanker og vurderinger, og man kan i den følgende proces ikke finde holdepunkter for den særlige betydning, som landsbyskolerne fik for landsbyfællesskabets opløsning. Bondeskolerne var ikke en funktion af landsbyfællesskabet; de holdt sig også i egne, hvor udskiftningen blev gennemført relativt tidligt. $\mathrm{Da}$ udskiftningsprocessen kom ind $i$ sin afsluttende fase efter 1770, kom initiativet udefra først og fremmest fra regeringen. Dr. Japsen mener, at statsmagten måtte træde i grandelagets sted, da det gamle kollektiv, der havde båret bondeskolerne, forsvandt. På baggrund af det foranstående vil man forstå, at jeg ikke kan dele denne opfattelse end ikke taget som en stærk forenkling. 
Når jeg hævder, at kun øvrighedsskolerne var udviklingsdygtige, mener jeg dermed, at kun ved det offentliges indgriben kunne der sikres lærerstanden en anstændig eksistens, og kun derved kunne nødtørftige minimalkrav til skolebygningernes indretning opfyldes, kun derved kunne fattige skolebørn få undervisning, kun derved kunne en almindelig skolepligt gennemføres. Dr. Japsen afviser, at kun ovrighedsskolerne var udviklingsdygtige ved at sige, at de to skoleformer var tilpasset hver sit historisk betingede miljø og udviklede sig inden for dettes grænse og mener, at jeg har målt bondeskolerne med den senere øvrighedsskoles alen og sidestillet bondeskolernes virkelighed med velmenende menneskers ønsker med hensyn til øvrighedsskolerne.

Her må jeg meget beklage at have brugt ordet »idealer« $\mathrm{i}$ stedet for "principper ", men bortset herfra har jeg forstået dr. Japsens bog således, at øvrighedsskoler og bondeskoler fandtes side om side gennem en lang periode, og det, jeg sammenligner, er ikke den senere øvrighedsskole med bondeskolerne, men de eksisterende øvrighedsskoler (der ofte var ringe nok) og de synspunkter, der var ledende allerede $\mathrm{i}$ datiden, og som efterhånden trængte igennem. Disse principper kunne ikke virkeliggøres inden for bondeskolens rammer, og når ordet »idealer « løb mig i pennen, var det, fordi jeg nærer den opfattelse, at der var bønder, som gerne havde fortsat de gamle bondeskoler længe endnu.

Det er dr. Japsens uvisnelige fortjeneste at have fremdraget bondeskolerne af glemselen; vi bliver måske ikke enige om forholdet mellem øvrighedsskoler og bondeskoler, men en doktorafhandling indbyder nu engang til debat; forhåbentlig vil denne også interessere andre end parthaverne, men frem for alt må det til slut fremhæves, at dr. Japsen med sin bog har ydet et helt grundlæggende arbejde for sønderjysk skolehistorie, hvorfor han fortjener den største tak.

Troels Fink. 